\title{
Analysis of Real Estate Project Market Localization
}

\author{
Jia Sheng', Ying Zhou', Shuqun $\mathbf{L i}^{2}$ \\ ${ }^{1}$ Department of Engineering Management Anhui Xinhua University, Hefei City, Anhui Province, China \\ ${ }^{2}$ Department of Architectural Engineering Hefei University, Hefei City, Anhui Province, China
}

\begin{abstract}
The development and the success of enterprises are determined by the real estate market localization, so real estate enterprises can get better benefits by the accurate localization. But there are many problems in China real estate market localization. The form and the importance of the real estate market localization are focused in this paper and then a successful real estate project is analyzed, hoping to provide other enterprises some good recommendations.
\end{abstract}

Index Terms - Real estate development project, Xinhua Institutions Spring Project, market localization

\section{The Importance and Content of Real Estate Project Market Localization}

\subsection{The importance of real estate project market localization}

From the big perspective, real estate project market localization analysis can better meet the needs of the people's material and cultural life, and promote the healthy and stable development of the national economy; From the little perspective, it can enable enterprises to achieve better development, to facilitate a smooth project carried out to achieve the investment, quality and duration of the three management objectives. It can not only provide a reliable basis for enterprises to make scientific decisions, but also help enterprises to improve the management level, reduce market risk as well as enhance market competitiveness, offer their products a stable marketability, train in all aspects of the product features, establish market image, make real estate products can more accurately meet consumer demand, and avoid waste of resources so that the real estate industry can go to a healthy, stable, good direction. ${ }^{[2]}$

\subsection{The content of real estate project market localization}

Real estate project market localization is the starting point and the return point of project planning, generally includes customer localization, product localization, price localization, image localization and brand localization. ${ }^{[3]}$

Firstly, customer localization is to identify target customer groups, and then project sales can be more accurate and effective through the thorough analysis of target customer groups. Generally, customer localization carries out by doing some reach on customer's economic and cultural backgrounds. Product localization refers to the production of real estate enterprises that meet the needs of target customers or the demands of target market, and it focus on the future potential customer. Specifically, the goal of product localization is to create certain characteristics and images which fit the customer's needs and preferences of product in the minds of customers. Price localization is closely related with product localization .It refers to set the price of real estate projects' level. The key is that this price should not only be received by consumers, but also should realize the benefits of enterprise. Image localization is closely related to its development strategy. It combines the image characteristics to consider the project as a whole in order to determine the concept to attract the attentions of consumers. This concept is refined and summarized to dig out the features and advantages of project, which can cause consumers' interests, stimulate and create demands, and trigger buying motives. ${ }^{[4]}$ Brand localization is built based on product localization for a particular brand determining an appropriate market position. So that projects can occupy a special position in the minds of consumers. Its purpose is to convert the product into a brand for a correct understanding of the customers.

\section{Overview of Xinhua Institutions Spring Project}

Xinhua Institutions Spring Project is a famous humane community in Hefei City. It is located in the intersection of Wangjiang Road and Qianshan Road, adjacent to the Swan Lake Park and more than ten universities, such as Anhui University, University of Science and Technology, with a total construction area of 300000 square meters. It combines the achievements of modern environmental planning, landscape art, architecture, technology, process units and community services.

\section{Market Research Analysis of Xinhua Institutions Spring Project}

\subsection{Analysis of Regional Environmental}

Xinhua Institutions Spring Project is located in Shushan Area. In October 2006, the real estate project sales of Areas in addition to the new station Area where the added amount is zero, the others rose in varying degrees.

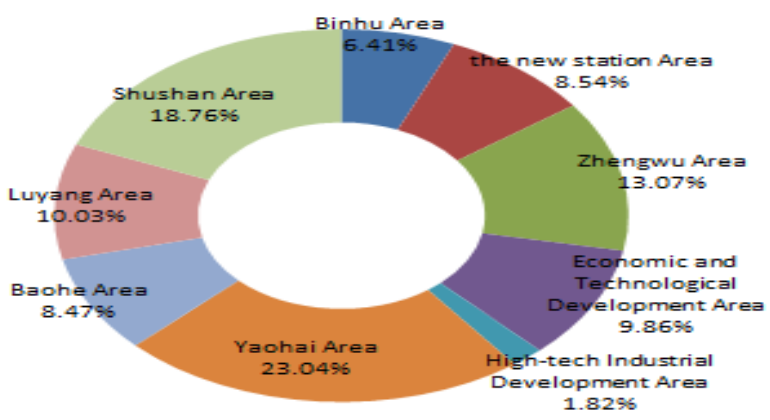

Fig. 1 The percent of real estate project sales in Hefei City

Fig. 1 shows that the real estate project sales of Shushan Area are very good, accounted for 18.76 percent of the city, second only to the Yaohai Area. 


\subsection{Analysis of Competitive environment}

This project is surrounded by some communities, e.g.
Lanxi Town, Camphor Villas and Greentown Lily Apartment. A simple liquidation is done under the table.

Table 1 Property of real estate analysis

\begin{tabular}{|l|l|l|l|}
\hline & Lanxi Town & Camphor Villas & Greentown Lily Apartment \\
\hline location & $\begin{array}{l}\text { Huangshan Road and Camphor Avenue } \\
\text { Interchange }\end{array}$ & Hezuohua South Road & $\begin{array}{l}\text { Dongzhi Road and Wangjiang West Road } \\
\text { Interchange }\end{array}$ \\
\hline property form & wide view house & small high-level & Small high-level, high-level, multi-level \\
\hline internal facilities & clubs, tennis courts, swimming pool & clubs, tennis courts, swimming pool, & kindergarten, primary school, tennis courts \\
\hline price & $4200 \sim 5600$ Yuan & $4500 \sim 4700$ Yuan & 3700 Yuan \\
\hline customers & $\begin{array}{l}\text { managements of enterprises and } \\
\text { institutions }\end{array}$ & $\begin{array}{l}\text { university teachers, civil servants, private } \\
\text { owners }\end{array}$ & teachers, civil servants, militaries \\
\hline $\begin{array}{l}\text { the advantage of } \\
\text { project }\end{array}$ & $\begin{array}{l}\text { developer brand, complimentary terrace } \\
\text { and basement, central heating }\end{array}$ & developer brand, property management & heating, specialty clubs \\
\hline
\end{tabular}

The table shows that there isn't obvious difference among Greentown Lily Apartment and Lanxi Town, Camphor Villas. Greentown Lily Apartment and Lanxi Town, Camphor Villas aren't great threats to Xinhua Institutions Spring Project. Xinhua Institutions Spring Project has great advantages in product quality, location, appreciation of space to enhance market competitiveness.

\section{SWOT analysis of Xinhua Institutions Spring Project}

SWOT analysis is to find appropriate business strategies which fit the actual situation of organization through analyze of strengths and weaknesses foamed by internal environment, opportunities and threats foamed by external environment. ${ }^{[5]}$

\subsection{The strengths analysis of Xinhua Institutions Spring \\ Project}

Firstly, the apartment layout is novel that will be favored by consumers. Secondly, the project is landscape structure, so the development prospect is broad. Thirdly, Consumers agree with products design, cultural image and corporate integrity of Xinhua Group.

\subsection{The weaknesses analysis of Xinhua Institutions Spring \\ Project}

Xinhua Institutions Spring Project is lightly polluted. It is adjacent to the street and shopping center, so the noise impact is relatively large and the air quality is not very good; the price of project is a little high, the problems of school district and marketing.

\subsection{The opportunities analysis of Xinhua Institutions Spring Project}

At the first, good location: Xinhua Institutions Spring Project is at the first station of the municipal government moved westward and the central area of Huangshan Road. It is rounded by companies, adjacent to the Swan Lake Park and some universities. So it has convenient transportations and a large passenger flow. Second, surrounding facilities are relatively perfect: it is adjacent to the street, there are Tesco, Joy Mart, Premier Foods Market, other supermarket and the
Agricultural Bank of China and Huishang Bank. Buses there are 8 Road, 10 Road, 118 Road, 121 Road, 129 Road and 706 Road.

\subsection{The threats analysis of Xinhua Institutions Spring Project}

The government issued stringent real estate policies, including price limit, purchase limit, bank loan interest rates. All these bring the real estate market some percussion and great influence on future of Hefei City.

\section{Market localization of Xinhua Institutions Spring Project}

\subsection{Customer localization of Xinhua Institutions Spring Project}

As can be seen from the fig. 2, the main of Xinhua Institutions Spring Project is between 31-45 years old, that customers above 50 years old accounted for only a small part and other age accounted for only $21 \%$. So the object of this project is to promote middle-age class.

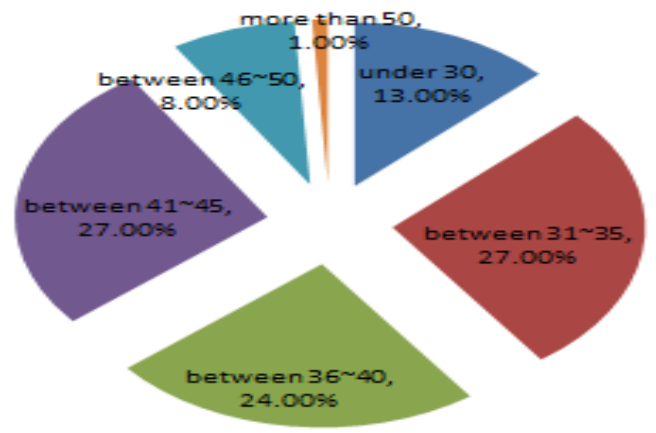

Fig. 2 The age distribution of customer

From the perspective of the customer education, undergraduate customers accounted for a dominant position with 71 percent, graduate and above is 12 percent, senior 12 percent and junior is 71 percent. The project is more attractive to high degree of customer groups. 


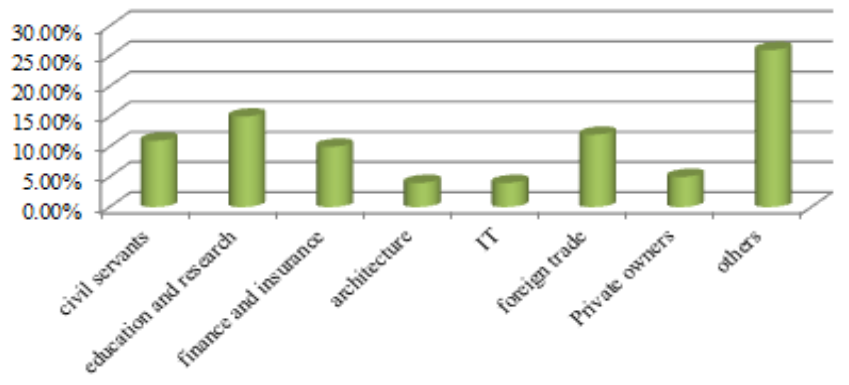

Fig. 3 The occupation attribute of customers

Fig. 3 shows that civil servants, people engaged in education and research, finance and insurance, foreign trade are the dominant. These customers generally have higher revenue, strong purchasing power and high-quality.

\subsection{Product localization of Xinhua Institutions Spring Project}

Institutions Gardens and Institutions Constellation early exploited by Xinhua Estate Company are high-end residential apartments; they have established Xinhua Estate Company brand in the mind of consumers. Xinhua Institutions Spring Project is located in a central location around the block, and its function can radiate around the block, Xinhua Institution Mingdu Project has set aside 30 acres of land near from this project. The product localization of this project plays a crucial role in enhancing the product value.

Xinhua Institutions Spring Project composes of small high-level, high-level, multi-level, landscape level, scenes villa and Lake Villa. It has 10000 square meters of garden, 30000 square meters of building and six theme parks, creating a rare urban greening rate and the largest artificial water region of humane community in Hefei City.

\subsection{The price localization of Xinhua Institutions Spring Project}

The price of Xinhua Institutions Spring Project locates above 4300 Yuan and cash benefits are different according to the area; under $127 \mathrm{~m}^{2}$ each house enjoy 4000 Yuan cash discount, between $127-146 \mathrm{~m}^{2}$ the discount is 6000 Yuan, between $146-160 \mathrm{~m}^{2}$ the discount is 8000 Yuan and above $160 \mathrm{~m}^{2}$ the discount is 8000 Yuan.

\subsection{The image localization of Xinhua Institutions Spring Project}

Generally, image localization is expressed by enterprise culture, advertising, packaging, brand, model, model of housing and other forms. The landscape of the project is designed by Collins Hong Kong Limited Company of American and the architectural is designed by Australia Portofino Company. It is a blend of modern landscape art, house craft, environmental planning, and construction technology, community services. It adheres to the peopleoriented business philosophy and deduces a high quality modern humanistic community. The project has gorgeous advertising packaging and the propaganda is good, which is praised by consumers. So the image localization of project can be summarized as: comfort, convenience, and beauty of life.

\section{Conclusion}

At present, real estate enterprises need to consider more about market prospects and the impact of macroeconomic policies on the real estate industry about real estate development and construction in our country, rational and calmly look at the development of real estate industry. The real estate companies during the market localization should fully consider customers, image, brand, product market strategies and innovative ideas to create new selling points about its product. Only through accurate market localization, real estate enterprises can achieve greater success.

\section{References}

[1] L.-Y. Ding, Real estate development. Beijing: China Architecture \& Building Press, 2008.

[2] P. Kotler, Marketing Management. Shanghai: Shanghai People's Publishing House, 2003.

[3] X.-K. Luo, Practice of real estate development project market localization. Chongqing: Chongqing University, 2009.

[4] S.-A. Yang, The preliminary planning of real estate development enterprise project. Urban Development, vol. 9, pp. 50-51, 2001.

[5] D.-Y. Zhou, the market localization of real estate development project. Inquiry into Economic Issues, vol. 11, pp. 108-109, 2003. 